\title{
The Role of Epicardial Adipose Tissue in Heart Disease
}

\author{
Z. MATLOCH ${ }^{1}$, T. KOTULÁK ${ }^{1}$, M. HALUZÍK ${ }^{2,3}$ \\ ${ }^{1}$ Department of Anesthesiology and Intensive Care, Institute for Clinical and Experimental \\ Medicine, Prague, Czech Republic, ${ }^{2}$ Institute of Endocrinology, Prague, Czech Republic, ${ }^{3}$ Institute \\ of Medical Biochemistry and Laboratory Diagnostics of the General University Hospital and of The \\ First Faculty of Medicine of Charles University in Prague, Prague, Czech Republic
}

Received March 14, 2015

Accepted August 20, 2015

On-line November 24, 2015

\section{Summary}

Recent studies focused on epicardial fat, formerly relatively neglected component of the heart, have elucidated some of its key roles. It possesses several properties that can distinguish it from other adipose tissue depots. Its unique anatomical location in the heart predisposes the epicardial fat to be an important player in the physiological and biochemical regulation of cardiac homeostasis. Obesity is associated with an increase in epicardial fat mass. Excess of cardiac fat can contribute to greater left ventricular mass and work, diastolic dysfunction and attenuated septal wall thickening. Imbalance in adipokines levels secreted in autocrine or paracrine fashion by epicardial fat can contribute to the activation of the key atherogenic pathways in the setting of metabolic syndrome. Epicardial fat has also been identified as an important source of pro-inflammatory mediators worsening endothelial dysfunction, eventually leading to coronary artery disease. Increased production of pro-inflammatory factors by epicardial fat can also contribute to systemic insulin resistance in patients undergoing cardiac surgery. Here we review the most important roles of epicardial fat with respect to heart disease in the context of other underlying pathologies such as obesity and type 2 diabetes mellitus.

\section{Key words}

Epicardial fat • Adipokines • Inflammation • Obesity • Type 2 diabetes mellitus

\section{Corresponding author}

M. Haluzik, Institute of Endocrinology, Národní 8, 116 94, Prague 1, Czech Republic. Fax: +420-224905325. E-mail: mhalu@lf1.cuni.cz

\section{Introduction}

There has been a growing interest in studying epicardial adipose tissue (EAT) over the last decade. Adipose tissue itself is now widely accepted to be an important endocrine and paracrine organ producing variety of active substances, which play a role in the development of obesity, metabolic syndrome and heart disease, especially coronary artery disease (CAD) (Sacks and Fain 2007). The purpose of this paper is to review anatomical and physiological features of EAT and to highlight current understanding of relationship between endocrine function of EAT, obesity and CAD.

\section{Anatomy and physiological function of epicardial fat}

The epicardium is the inner serous layer of the pericardium formed by mesothelial cells and lying directly upon the heart. In the embryological phase these cells migrate onto the surface of the heart from the part of septum transversum. Mesenteric, omental and epicardial fat all originate from the splanchnopleuric mesoderm, related with the gut (Ho et al. 1978). EAT is, in the normal adult, localized on the free wall of the right ventricle, around the left ventricular apex, atria and two appendages. It also extends from the surface of the myocardium along the adventitia of the coronary artery branches (Iacobellis et al. 2005). According to some studies, the EAT plus paracardial fat form pericardial 
adipose tissue (PAT) (Wheeler et al. 2005). Paracardial fat is distributed within the mediastinum on the external surface of the parietal pericardium (Sironi et al. 2004). Paracadial fat evolved from the primitive thoracic mesenchyme, which divides to form the outer thoracic wall and parietal pericardium (Sacks et al. 2007). The blood supply of paracardial fat is mainly from the pericardiophrenic artery, a branch of the internal mammary artery. Contrary to that, the EAT and muscular components of the heart have so close anatomical and functional relationship (e.g. no firm layer resembling fascia), that they share the same coronary blood supply (Fig. 1).
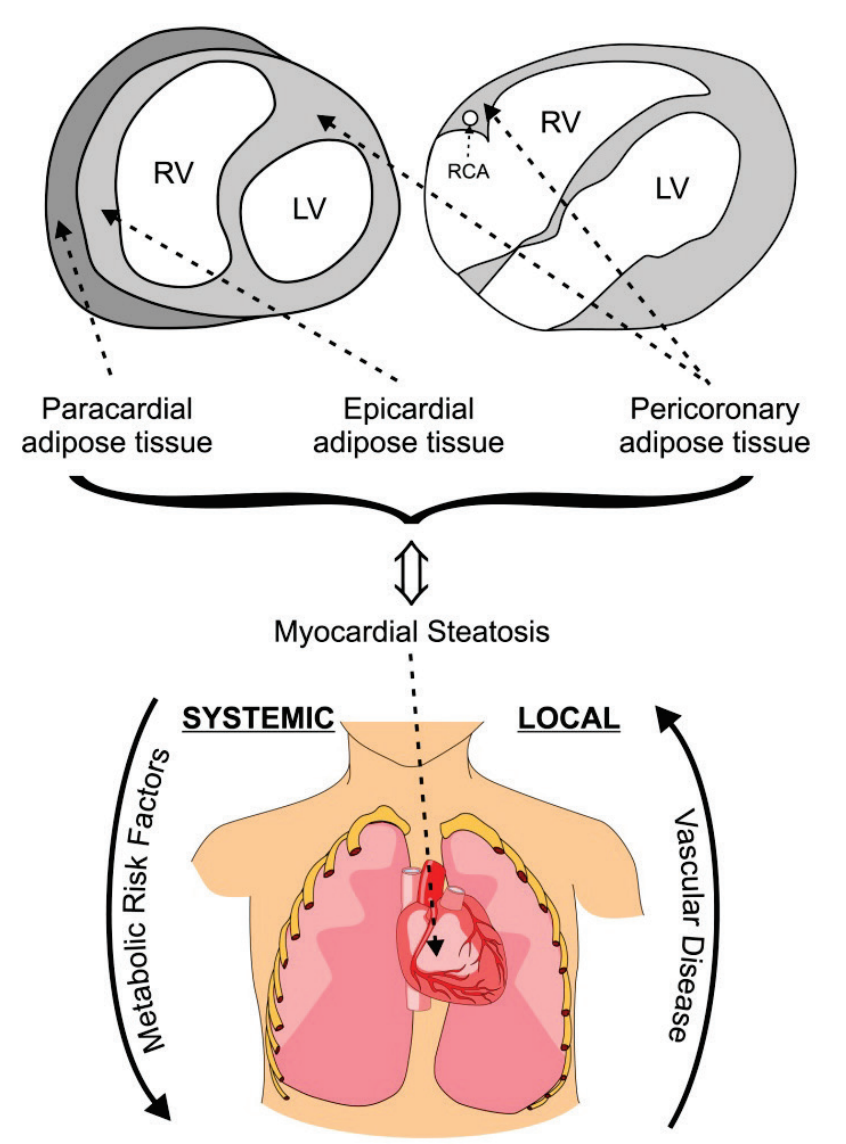

Fig. 1. Anatomical localization and scheme of relative quantities of paracardial, epicardial and pericoronary fat as derived from computed tomography (modified from Gorter et al. 2008) and schematic representation of systemic and local effects of fat depots surrounding myocardium and intramyocardial fat (modified from Britton and Fox 2011).

Most of the suggested physiological functions of the EAT are based on observational data. There is limited clinical evidence from human studies and most animals used for experimental manipulation have only a little epicardial fat (Marchington et al. 1989). Coronary arteries are always covered by epicardial fat, hence putative buffering role against twist and tension of the coronary arteries caused by the arterial pulse wave. In other words, the EAT provides a cushion, in which coronaries may easily expand (Keegan et al. 2004). The EAT may also play a role in the fatty acids homeostasis in coronary arteries (Marchington et al. 1990). This function is based on a fact of high metabolic rate of fatty acids in the EAT surrounding coronaries. Authors further propose that this fat may serve as a local energy depot for cardiac muscle in times of high demand. Another possible function of the EAT is coronary artery remodeling. Positive remodeling is more likely to occur when an atherosclerotic plaque is surrounded by epicardial fat, which allows for some expansion rather than in those coronary lesions surrounded by worse compressible myocardium (Glagov et al. 1987, Ward et al. 2001). Eventually, there is some evidence that the EAT may be part of the skeleton for the intrinsic cardiac nervous system, as the so called ganglionated plexuses can be found in epicardial fat in five atrial and six ventricular regions (Arora et al. 2003). Some authors even propose that these neurons could mediate the pain of angina pectoris (Sylven 1993).

\section{Obesity and heart disease}

Obesity is a major clinical problem in developed societies. It is defined as a body mass index (BMI) of greater or equal to $30 \mathrm{~kg} / \mathrm{m}^{2}$ (Haslam and James 2005). It is often associated with a number of other diseases like dyslipidemia, insulin resistance and hypertension. These 4 conditions are also referred as a metabolic syndrome (MetS) (Shaw and Chisholm 2003). The International Obesity Taskforce (IOTF) estimates that there is roughly 1 billion of overweight adults (BMI $25-29.9 \mathrm{~kg} / \mathrm{m}^{2}$ ), and of these 475 million are obese ( $\geq 30 \mathrm{~kg} / \mathrm{m}^{2}$ ) (IOTF 2010). It is well known that obesity and MetS are associated with increased morbidity and mortality. Generally, more fat is attached to the right than the left ventricle and the average ratio of epicardial fat/gram of heart muscle is 0.15 in men and 0.17 in women for the left ventricle. Regarding the right ventricle the ratio is 0.48 and 0.61 grams respectively (Corradi et al. 2004). Interestingly, some authors documented no correlation between BMI and coronary atherosclerosis. However, the patients with atherosclerotic lesions have higher volumes of pericardial fat than those without lesions (Greif et al. 2009). 
Furthermore, numerous studies report that the body fat distribution predetermines clinical consequences. For instance, visceral intra-abdominal obesity has been linked with increased cardiometabolic risk and mortality (Fox et al. 2007, Gesta et al. 2007). Additionally, increased amount of gluteofemoral fat has been negatively associated with levels of proinflammatory cytokines and positively associated with elevated concentrations of adipokines leading to decreased cardiometabolic risk (Manolopoulos et al. 2010). One of the important mechanisms contributing to an increased cardiovascular risk in patients with obesity and type 2 diabetes mellitus is disturbed endocrine function of adipose tissue (Trachta et al. 2014, Urbanova et al. 2014, Bluher 2009).

There is a theory, that from the time of our ancestors, the fat depots served as energy storage in times of plenty, and could then be burned during starvation (Neel 1962). Genes predisposing to obesity would then bring certain survival benefits to these individuals to live long enough to reproduce. According to some studies, the breakdown of this system might be responsible for current issues associated with obesity, resulting in a fact that susceptible individuals do not suffer from the famine period anymore and instead incline to overeating high caloric food (Diamond 2003). Interestingly, in hibernating mammals, short-term obesity and insulin resistance have rather advantageous effect of directing glucose to the brain; only man has developed chronic obesity linked with morbidity and mortality (Scott and Grant 2006).

Considering a physical activity and its impact on epicardial fat thickness, there was greater percent reduction in epicardial fat adiposity than in waist circumference (WC) and BMI area after 12-week exercise training, and the change was independent to systolic blood pressure and insulin sensitivity changes (Kim et al. 2009).

In obesity and type 2 diabetes mellitus, the intramyocardial triglyceride stores are increased two to four-fold compared to a control group of lean patients. Excess of cardiac fat contributes to greater left ventricular (LV) mass and work, diastolic dysfunction and attenuated septal wall thickening (Iozzo et al. 2009). It may also precipitate increased arrhythmogenicity, electrocardiographic abnormalities and cardiac failure (Poirer et al. 2006). On the contrary, the phenomenon of "obesity paradox" has been described. Gruberg et al. (2002) found better outcomes in overweight patients with
CAD undergoing percutaneous coronary intervention (PCI) compared to their normal-weight counterparts. Over the last years further studies have documented that the obesity paradox or reverse epidemiology is specific not only for CAD patients undergoing PCI. Protective effects of obesity have also been discussed in other chronic diseases (Lainscak et al. 2012, Hainer and Hainerova 2013). Conditions associated with peripheral arterial disease, stroke, thromboembolism, postoperative complications in patients after cardiac surgery, type 2 diabetes and cardiovascular comorbidity, chronic obstructive pulmonary disease, hemodialysis patients and osteoporosis have all to a certain degree better outcome in overweight and obese patients (Hainer and Hainerova 2013).

\section{Is there a specific role of EAT in heart disease?}

The Framingham Heart Study and the MultiEthnic Study of Atherosclerosis found that the size of fat depots around the heart is independent risk predictors for cardiovascular dysfunction and CAD (Mahabadi et al. 2009, Rosito et al. 2008, Ding et al. 2009). Namely, periaortic fat depots correlated with BMI, waist circumference, visceral abdominal tissue (VAT), hypertension, lower HDL, impaired fasting glucose, including diabetes and serum triglycerides. Even after adjustments for BMI and WC, these associations remained significant. Furthermore, peri-aortic fat also correlated with coronary and abdominal aortic calcifications (Lehman et al. 2010). EAT volume and thickness were increased in patients suffering from CAD compared to patients with normal coronary arteries, and in patients with unstable angina as compared to patients with stable angina. Also EAT volume was larger in patients suffering from obstructive CAD and increased coronary artery calcium score (Djaberi et al. 2008, Sarin et al. 2008, Silaghi et al. 2008).

Fatty heart and diastolic dysfunction are usually found together in metabolic disorders. However, their changes induced by metabolic interventions, in terms of short-term caloric restriction or high-fat diets of short duration, are not always correlated (Lamb et al. 2008, van der Meer et al. 2009), suggesting that other pathologic processes in patients with both diabetes and obesity may be more responsible for the dysfunction. The overload of fatty acids in obese diabetics is followed by primary hyperactivation of $\beta$-oxidation, leading to excess 
production of reactive oxygen species (ROS). It leads to modulation of sarcoplasmic reticulum $\mathrm{Ca}^{2+}$-ATPase, marked as early contributor to diastolic dysfunction, myocardial hypertrophy and fibrosis in insulin-resistant myocardium (Ritchie 2009). Additionally, expression of mRNA for catalase, glutathione S-transferase $\mathrm{P}$ and protein disulfide isomerase, related to ROS, is higher in EAT than in subcutaneous adipose tissue (SAT) in patients undergoing heart surgery. Authors suggest, that in patients with CAD, the EAT suffers greater oxidative stress than SAT (Salgado-Somoza et al. 2010). The role of solely accumulated triglycerides in the pathogenesis of heart disease remains unclear. Transgenic overexpression of diacylglycerol acyltransferase 1 (DGAT 1) in the heart (the triglyceride-synthesizing enzyme) leads to a physiologic hypertrophy possessing some protective functions in lipid overdose hearts (Liu et al. 2009). Furthermore, in the non-ischemic failing human heart compared with the healthy one, cardiac triglyceride content was either reduced (Walecki et al. 2003) or unchanged in patients without diabetes or obesity (Sharma et al. 2004). Contrary to that, myocardial fatty acid oxidation was activated in diabetics and obese patients with fatty heart. These studies further speculate that triglyceride accumulation could be regarded as a maladaptive defense response, leading via peroxidation and saturation to accumulation of toxic lipid intermediates in the cytoplasm, eventually fostering the functional damage to the heart. It implies that the buildup of myocardial triglycerides can be understood as an indirect marker of cardiac dysfunction in selected stages of heart disease.

There is evidence that diabetes is associated with a cardiomyopathy, independent of other comorbidities. The most important mechanisms leading to diabetic cardiomyopathy are metabolic disturbances (e.g. depletion of glucose transporter 4, carnitine deficiency, increased free fatty acids, affected calcium homeostasis), myocardial fibrosis (association with increases in angiotensin II, insulin-like growth factor $\mathrm{I}$ and inflammatory cytokines), small vessel disease (e.g. endothelial dysfunction, microangiopathy, and impaired coronary flow reserve), autonomic neuropathy (denervation and alterations in myocardial catecholamine levels), and insulin resistance (hyperinsulinemia and altered insulin sensitivity) (Fang et al. 2004).

Substrates cannot enter cardiomyocytes by simple diffusion and must be taken up by facilitated transport. Fatty acids are taken up by FAT (fatty acid translocase, also called as cluster of differentiation 36, CD36), and glucose transporter type 4 (GLUT4) transfers glucose. In case of insulin resistance during type 2 diabetes mellitus, FAT/CD36 becomes preferentially sarcolemma-localized, on the other hand GLUT4 is internalized. This shift is responsible for aberrant substrate uptake in diabetes, where the glucose metabolism is attenuated and fatty acid metabolism is chronically increased (Schwenk et al. 2008, Steinbusch et al. 2011). Also Forkhead transcription factors play an important role in diabetic cardiomyopathy. Battiprolu et al. (2013) highlighted recently the importance of chronic activation of FoxOs (forkhead box-containing protein) in the pathogenesis of diabetic cardiomyopathy. Importantly, cardiomyocyte-specific inactivation of FoxO1 reversed high-fat diet-induced hypertrophy and thus decline in cardiac function while preserving cardiomyocyte insulin sensitivity. Additionally, there is also increasing number of animal studies differentiating the mechanisms and effects of diabetic cardiomyopathy caused by type 1 versus type 2 diabetes. Although left ventricle systolic dysfunction is present in both, it is more prevalent in type 1 diabetes. Contrary to that, type 2 diabetes has greater impairment of ventricular filling, associated with diastolic dysfunction (Fang et al. 2004). Exact mechanisms for the differences between cardiomyopathy in type 1 diabetes and type 2 diabetes are unknown. However, some possible explanations include insulin resistance with its attenuated protective effects to ischemic reperfusion and also functional cardiomyocyte alterations due to augmented fatty acid metabolism and hyper-triglyceridemia and ROS in type 2 diabetes (Isfort et al. 2014).

\section{Endocrine function of EAT and heart disease}

Adipose tissue is well recognized as a dynamic endocrine organ producing a number of bioactive molecules that can affect not only energy metabolism, but also vascular, inflammatory and immunologic responses. Recently, the relationship of EAT echocardiographic thickness and inflammatory profile between patients with severe, calcific aortic stenosis (AS) and healthy subjects have been tested. The ETA thickness was markedly increased in patients with AS compared to control group. Also several inflammatory and pro-atherogenic mediators, especially IL-6, IL-1 $\beta$ and TNF- $\alpha$ were significantly increased in EAT compared to plasma levels in patients with AS. These findings support the 
hypothesis of an involvement of ETA in atherogenic and inflammatory phenomena in the aortic valve and its promotion to calcific AS (Parisi et al. 2015). Mazurek and colleagues (2003) compared the expression of cytokines in both EAT and SAT in patients undergoing coronary artery bypass graft and found that epicardial adipose tissue expresses a wide range of inflammatory mediators. Epicardial fat had a significantly higher expression of monocyte chemotactic protein-1 (MCP-1), interleukin-1 $\beta$ (IL-1 $\beta$ ), interleukin-6 (IL-6), interleukin-6 soluble receptor (IL- 6 sr) and tumor necrosis factor- $\alpha$ (TNF- $\alpha$ ) than subcutaneous fat. Furthermore, authors suggest that TNF- $\alpha$ derived from adipocyte, may act in an autocrine fashion, impairing the insulin receptor signaling and increasing lipolysis. Resultant release of nonesterified fatty acids may contribute to insulin resistance in adipose and muscle tissue, plus in the liver and the heart. However, there was no correlation between EAT inflammation and diabetes, obesity and LDL plasma levels. Additionally, such relationship was found neither with intake of statins, angiotensin-converting enzyme inhibitors nor angiotensin-receptor blockers. Mazurek et al. (2003) further proposes the hypothesis that the presence of inflammatory mediators, such as TNF- $\alpha$ in EAT around coronaries could amplify vascular inflammation, plaque instability and neovascularization. These effects could mean that the bioactive molecules released from the perivascular adipose tissue alter arterial homeostasis.

Other studies further demonstrated expression of numerous EAT adipokines, including adiponectin, omentin, adipsin, leptin, resistin, adrenomedullin, visfatin and chemerin. In particular, leptin, resistin and TNF- $\alpha$ have all diminished endothelial-dependent vasodilation, when administered experimentally (Beltowski et al. 2004). Endothelial dysfunction is hypothesized to be the first step in the development of atherogenesis. The concept was first proposed by Ross and Glomset (1973). In contrast, adiponectin has been associated with endothelial improvement via endothelial NO synthase (eNOS)-dependent pathways (Li et al. 2007, Deng et al. 2010). In the setting of obesity, as the pro-inflammatory status, adiponectin has been shown to reduce the oxidative stress, further protecting endothelium ( $\mathrm{Li}$ et al. 2007). In uniquely designed study on patients undergoing coronary artery bypass graft surgery, local adiponectin gene expression and ex vivo release were measured in mesothoracic adipose tissue and in perivascular (internal mammary artery and saphenous vein) subcutaneous tissue. Circulating adiponectin was independently associated with $\mathrm{O}_{2}^{-}$production/eNOS uncoupling and nitric oxide bioavailability in both arteries and veins. This finding shows that adiponectin might improve the redox state in human vessels by restoration of eNOS coupling (Margaritis et al. 2013). Furthermore, while the EAT expression of resistin, leptin and TNF- $\alpha$ is increased in obesity, adiponectin is markedly diminished (Cheng et al. 2008, Greif et al. 2009).

Especially leptin has been recently blamed for many key aspects of atherogenesis, including chemoattraction of monocytes (Gruen et al. 2007), decreasing high density lipoproteins (HDL) and apolipoprotein AI concentration (Rainwater et al. 1997), accumulation of cholesterol esters in foam cells (O'Rourke et al. 2007) and activation of C-reactive protein (CRP) and serum amyloid A (Kazumi et al. 2003). By all these means, leptin increases oxidative stress, leads to endothelial dysfunction, increases inflammation and smooth muscle proliferation, recruits monocytes and via macrophages accelerates the formation of foam cells. This has been proposed as a key cascade in atherogenic pathways in the setting of the MetS. Importantly, a recombinant adiponectin can successfully reverse some of these harmful effects of EAT-derived factors (Karastergiou et al. 2010). Some newer experimental studies also suggest that perivascular adipose tissue can foster neointimal hyperplasia, adventitial angiogenesis and adventitial macrophage infiltration in mice model of wire injury. This process was partly due to MCP-1-dependent mechanisms (Manka et al. 2014).

We have studied subcutaneous and EAT production of pro-inflammatory cytokines (e.g. CD14, CD45 and CD68) in cardiac surgical patients and came to a conclusion that both fat tissues become a significant source of pro-inflammatory cytokines during surgery and postoperatively and thus possibly contributing to the development of insulin resistance in these patients (Kremen et al. 2006). Furthermore, we have recently shown that also the skeletal and EAT mRNA expression of a novel hormone involved in metabolic regulations fibroblast growth factor-21 (FGF-21) increase during cardiac surgery. Muscle FGF-21 mRNA positively correlated with blood glucose levels towards the end of surgery. These data suggest that FGF-21 might play a role in metabolism of glucose and insulin resistance during surgery-related stress (Kotulak et al. 2010). Additionaly, we have found that the expression of 
angiotensinogen mRNA significantly increased in EAT at the end of cardiac surgery relative to baseline values but remained unchanged in subcutaneous adipose tissue. The expression of angiotensin-converting enzyme and type 1 receptor for angiotensin II in a fat were not affected by surgery. This data suggest that increased angiotensinogen production in EAT could contribute to postoperative insulin resistance (Roubicek et al. 2008). Another evidence for an important regulatory role of epicardial adipose tissue comes from the study exploring adipocyte fatty acid binding protein (A-FABP) in cardiac surgery patients. Here we found markedly increased serum levels of adipocyte fatty acid binding protein (A-FABP) at the end of cardiac surgery, compared to preoperative values. There was no difference between diabetic and nondiabetic patients at any time point. A-FABP mRNA expression was increased in peripheral monocytes, but no effect of surgery was detected in a muscle or adipose tissue. These findings suggest that serum A-FABP may be involved in stress-related response, contributing to insulin resistance and hyperglycemia, irrespective of the presence of diabetes mellitus (Kotulak et al. 2014). Collectively, these studies suggest an active contribution of endocrine function of EAT to the regulation of heart metabolism and its response to obesity, type 2 diabetes mellitus and other pathologies.

\section{Conclusion and future perspectives}

Epicardial adipose tissue is an important modulator of cardiac function through metabolic, endocrine and paracrine fashion. Despite improved understanding of its mode of action numerous mechanisms are still only partially understood. From the histopathological point of view, there are various subsets of macrophages in plaques and EAT, with distinct surface antigens and receptors (Tacke et al. 2007). The intramural movement of these cells could be tracked to distinguish their appropriate function. Additionally, macrophage density could be measured in autopsy samples from lean and obese patients with or without CAD.

Furthermore, animal experimental studies involving EAT should be performed on animals with reasonable amount of EAT such as pigs or rabbits on high fat diet with induced hyperlipidemia and atherosclerosis. These animals, however more expensive to work with, are more suitable than rodents that normally have little or no EAT, to examine the relationship between coronary atherosclerosis and adipokines secretions from EAT (Marchington et al. 1989).

Clinical studies should focus on the role of EAT as a biomarker of CAD, cerebral vascular disease and peripheral vascular disease. Biopsies of EAT are feasible to obtain from patients undergoing cardiac surgery. Different patient groups can be selected, either according to the nature of the procedure, or with or without concomitant diabetes, acute or chronic heart failure. However, it is difficult to justify EAT biopsies from weight-matched control group of patients without CAD.

In conclusion, EAT appears to be an important player in the development of coronary atherosclerosis and obesity- and diabetes-induced heart dysfunction. In spite of all the above described findings, the pathophysiological link between adipokines, endothelial dysfunction, atherogenesis, diabetes and obesity-induced CAD still needs to be elucidated further.

\section{Conflict of Interest}

There is no conflict of interest.

\section{Acknowledgements}

Supported by RVOVFN64165 and NV15-26854A.

\section{References}

ARORA RC, WALDMANN M, HOPKINS DA, ARMOUR JA: Porcine intrinsic cardiac ganglia. Anat Rec A Discov Mol Cell Evol Biol 271: 249-258, 2003.

BATTIPROLU PK, LOPEZ-CRISOTO C, WANG ZV, NEMCHENKO A, LAVANDERO S, HILL JA: Diabetic cardiomyopathy and metabolic remodeling of the heart. Life Sci 92: 609-615, 2013.

BELTOWSKI J, WOJCICKA G, MARCINIAK A, JAMROZ A: Oxidative stress, nitric oxide production, and renal sodium handling in leptin-induced hypertension. Life Sci 74: 2987-3000, 2004.

BLUHER M: Adipose tissue dysfunction in obesity. Exp Clin Endocrinol Diabetes 117: 241-250, 2009.

BRITTON KA, FOX CS: Ectopic fat depots and cardiovascular disease. Circulation 124: 837-841, 2011. 
CHENG KH, CHU CS, LEE KT, LIN TH, HSIEH CC, CHIU CC, VOON WC, SHEU SH, LAI WT: Adipocytokines and proiflammatory mediators from abdominal and epicardial adipose tissue in patients with coronary artery disease. Int J Obes 32: 268-274, 2008.

CORRADI D, MAESTRI R, CALLEGARI S, PASTORI P, GOLDONI M, LUONG TV, BORDI C: The ventricular epicardial fat is related to the myocardial mass in normal, ischemic and hypertrophic hearts. Cardiovasc Pathol 13: 313-316, 2004.

DIAMOND J: The double puzzle of diabetes. Nature 423: 599-602, 2003.

DING J, HSU FC, HARRIS TB, LIU Y, KRITCHEVSKY SB, SZKLO M, OUYANG P, ESPELAND MA, LOHMAN KK, CRIQUI MH, ALLISON M, BLUEMKE DA, CARR JJ: The association of pericardial fat with incident coronary heart disease: Multi-Ethnic Study of Atherosclerosis (MESA). Am J Clin Nutr 90: 499-504, 2009.

DENG G, LONG Y, YU YR, LI MR: Adiponectin directly improves endothelial dysfunction in obese rats through the AMPK-eNOS pathway. Int J Obes (Lond) 34: 165-171, 2010.

DJABERI R, SCHUIJF JD, VAN WERKHOVEN JM, NUCIFORA G, JUKEMA JW, BAX JJ: Relation of epicardial adipose tissue to coronary atherosclerosis. Am J Cardiol 102: 1602-1607, 2008.

FANG ZY, PRINS JB, MARWICK TH: Diabetic cardiomyopathy: evidence, mechanisms, and therapeutic implications. Endocr Rev 25: 543-567, 2004.

FOX CS, MASSARO JM, HOFFMANN U, POU KM, MAUROVICH-HORVAT P, LIU CY, VASAN RS, MURABITO JM, MEIGS JB, CUPPLES LA, D'AGOSTINO RB SR, O'DONNELL CJ: Abdominal visceral and subcutaneous adipose tissue compartments: association with metabolic risk factors in the Framingham Heart Study. Circulation 116: 39-48, 2007.

GESTA S, TSENG YH, KAHN CR: Developmental origin of fat: tracking obesity to its source. Cell 131: 242-256, 2007.

GLAGOV S, WEISENBERG E, ZARINS CK, STANKUNAVICIUS R, KOLETIS GJ: Compensatory enlargement of human atherosclerotic coronary arteries. $N$ Engl J Med 316: 1371-1375, 1987.

GORTER PM, DE VOS AM, VAN DER GRAAF Y, STELLA PR, DOEVENDANS PA, MEIJS MFL, PROKOP M, VISSEREN FLJ: Relation of epicardial and pericoronary fat to coronary atherosclerosis and coronary artery calcium in patients undergoing coronary angiography. Am J Cardiol 102: 380-385, 2008.

GREIF M, BECKER A, VON ZIEGLER F, LEBHERZ C, LEHRKE M, BROEDL UC, TITTUS J, PARHOFER K, BECKER C, REISER M, KNEZ A, LEBER AW: Pericardial adipose tissue determined by dual source CT is a risk factor for coronary atherosclerosis. Arterioscler Thromb Vasc Biol 29: 781-786, 2009.

GRUBERG L, WEISSMAN NJ, WAKSMAN R, FUCHS S, DEIBLE R, PINNOW EE, AHMED LM, KENT KM, PICHARD AD, SUDDATH WO, SATLER LF, LINDSAY J JR: The impact of obesity on the short-term and ong-term outcomes after percutaneous coronary intervention: the obesity paradox? J Am Coll Cardiol 39: 578-584, 2002.

GRUEN ML, HAO M, PISTON DW, HASTY AH: Leptin requires canonical migratory signaling pathways for induction of monocyte and macrophage chemotaxis. Am J Physiol Cell Physiol 293: C1481-C1488, 2007.

HAINER V, HAINEROVA IA: Obesity paradox does exist. Diabetes Care 36: 276-281, 2013.

HASLAM DW, JAMES WP: Obesity. Lancet 366: 1197-1209, 2005.

HO E, SHIMADA Y: Formation of the epicardium studied with the scanning electron microscope. Dev Biol 66: 579-585, 1978.

IACOBELLIS G, CORRADI D, SHARMA AM: Epicardial adipose tissue: anatomic, biomolecular and clinical relationships with the heart. Nat Clin Pract Cardiovasc Med 2: 536-543, 2005.

IOTF: Obesity the global epidemic. Vol. 2010.

IOZZO P, LAUTAMAKI R, BORRA R, LEHTO HR, BUCCI M, VILJANEN A, PARKKA J, LEPOMAKI V, MAGGIO R, PARKKOLA R, KNUUTI J, NUUTILA P: Contribution of glucose tolerance and sex to cardiac adiposity. J Clin Endocrinol Metab 94: 4472-4482, 2009.

ISFORT M, STEVENS SCW, SCHAFFER S, JONG CJ, WOLD LE: Metabolic dysfunction in diabetic cardiomyopathy. Heart Fail Rev 19: 35-48, 2014. 
KARASTERGIOU K, EVANS I, OGSTON N, MIHEISI N, NAIR D, KASKI JC, JAHANGIRI M, MOHAMED-ALI $\mathrm{V}$ : Epicardial adipokines in obesity and coronary artery disease induce atherogenic changes in monocytes and endothelial cells. Arterioscler Thromb Vasc Biol 30: 1340-1346, 2010.

KAZUMI T, KAWAGUCHI A, HIRANO T, YOSHINO G: C-reactive protein in young, apparently healthy men: associations with serum leptin, QTc interval, and high-density lipoprotein-cholesterol. Metabolism 52: 11131116, 2003.

KIM MK, TOMITA T, KIM MJ, SASAI H, MAEDA S, TANAKA K: Aerobic exercise training reduces epicardial fat in obese men. $J$ Appl Physiol 106: 5-11, 2009.

KOTULAK, T, DRAPALOVA J, KOPECKY P, LACINOVA Z, KRAMAR P, RIHA H, NETUKA I, MALY J, HOUSA D, BLAHA J, SVACINA S, HALUZIK M: Increased circulating and epicardial adipose tissue mRNA expression of fibroblast growth factor-21 after cardiac surgery: possible role in postoperative inflammatory response and insulin resistance. Physiol Res 60: 757-767, 2011.

KOTULAK T, DRAPALOVA J, LIPS M, LACINOVA Z, KRAMAR P, RIHA H, NETUKA I, MALY J, BLAHA J, LINDNER J, SVACINA S, MRAZ M, HALUZIK M: Cardiac surgery increases serum concentrations of adipocyte fatty acid-binding protein and its mRNA expression in circulating monocytes but not in adipose tissue. Physiol Res 63: 83-94, 2014.

KREMEN J, DOLINKOVA M, KRAJICKOVA J, BLAHA J, ANDERLOVA K, LACINOVA Z, HALUZIKOVA D, BOSANSKA L, VOKURKA M, SVACINA S, HALUZIK M: Increased subcutaneous and epicardial adipose tissue production of proinflammatory cytokines in cardiac surgery patients: possible role in postoperative insulin resistance. J Clin Endocrinol Metab 91: 4620-4627, 2006.

LAMB HJ, SMIT JW, VAN DER MEER RW, HAMMER S, DOORNBOS J, DE ROOS A, ROMIJN JA: Metabolic MRI of myocardial and hepatic triglyceride content in response to nutritional interventions. Curr Opin Clin Nutr Metab Care 11: 573-579, 2008.

LEHMAN SJ, MASSARO JM, SCHLETT CL, O'DONELL CL, HOFFMANN U, FOX CS: Peri-aortic fat, cardiovascular disease risk factors, and aortic calcification: The Framingham Heart Study. Atherosclerosis 210: 656-661, 2010.

LI R, WANG WQ, ZHANG H, YANG X, FAN Q, CHRISTOPHER TA, LOPEZ BL, TAO L, GOLDSTEIN BJ, GAO F, MA XL: Adiponectin improves endothelial function in hyperlipidemic rats by reducing oxidative/nitrative stress and differential regulation of eNOS/iNOS activity. Am J Physiol Endocrinol Metab 293: E1703-E1708, 2007.

LIU L, SHI X, BHARADWAJ KG, IKEDA S, YAMASHITA H, YAGYU H, SCHAFFER JE, YU YH, GOLDBERG IJ: DGAT1 expression increases heart triglyceride content but ameliorates lipotoxicity. $J$ Biol Chem 284: 36312-36323, 2009.

KEEGAN J, GATEHOUSE PD, YANG GZ, FIRMIN DN: Spiral phase velocity mapping of left and right coronary artery blood flow: correlation for through-plane motion using selective fat-only excitation. $J$ Magn Reson Imaging 20: 953-960, 2004.

MAHABADI AA, MASSARO JM, ROSITO GA, LEVY D, MURABITO JM, WOLF PA, O'DONNELL CJ, FOX CS, HOFFMANN U: Association of pericardial fat, intrathoracic fat, and visceral abdominal fat with cardiovascular disease burden: The Framingham Heart Study. Eur Heart J 30: 850-856, 2009.

MANKA D, CHATTERJEE TK, STOLL LL, BASFORD JE, KONANIAH ES, SRINIVASAN R, BOGDANOV VY, TANG Y, BLOMKALNS AL, HUI DY, WEINTRAUB NL: Transplanted perivascular adipose tissue accelerates injury-induced neointimal hyperplasia: role of monocyte chemoattractant protein-1. Arterioscler Thromb Vasc Biol 34: 1723-1730, 2014.

MANOLOPOULOS KN, KARPE F, FRAYN KN: Gluteofemoral body fat as a determinant of metabolic health. Int $J$ Obes (Lond) 34: 949-959, 2010.

MARCHINGTON JM, POND CM: Site-specific properties of pericardial and epicardial adipose tissue, the effects of insulin and high-fat feeding on lipogenesis and the incorporation of fatty acids in vitro. Int J Obes 14: 1013$1022,1990$.

MARCHINGTON JM, MATTACKS CA, POND CM: Adipose tissue in the mammalian heart and pericardium: structure, fetal development and biochemical properties. Comp Biochem Physiol B 94: 225-232, 1989. 
MARGARITIS M, ANTONOPOULOS AS, DIGBY J, LEE R, REILLY S, COUTINHO P, SHIRODARIA CH, SAYEED R, PETROU M, DE SILVA R, JALILZADEH S, DEMOSTHENOUS M, BAKOGIANNIS C, TOUSOULIS D, STEFANADIS C, CHOUDHURY RP, CASADEI B, CHANNON KM, ANTONIADES C: Interactions between vascular wall and perivascular adipose tissue reveal novel roles for adiponectin in the regulation of endothelial nitric oxide synthase function in human vessels. Circulation 127: 2209-2221, 2013.

MAZUREK T, ZHANG LF, ZALEWSKI A, MANNION JD, DIEHL JT, HWYDA A, SAROV-BLAT L, O'BRIEN S, KEIPER EA, JOHNSON AG, MARTIN J, GOLDSTEIN BJ, SHI Y: Human epicardial adipose tissue is a source of inflammatory mediators. Circulation 108: 2460-2466, 2003.

NEEL JV: Diabetes mellitus: a "thrifty" genotype rendered detrimental by "progress"? Am J Hum Genet 14: 353-362, 1962.

O'ROURKE L, YEAMAN SJ, SHEPHERD PR: Insulin and leptin acutely regulate cholesterol ester metabolism in macrophages by novel signaling pathways. Diabetes 50: 955-961, 2001.

PARISI V, RENGO G, PAGANO G, D'ESPOSITO V, PASSARETTI F, CARUSO A, GRIMALDI MG, LONOBILE T, BALDASCINO F, DE BELLIS A, FORMISANO P, FERRARA N, LEOSCO D: Epicardial adipose tissue has an increased thickness and is a source of inflammatory mediators in patients with calcific aortic stenosis. Int $J$ Cardiol 186: 167-169, 2015.

POIRER P, GILES TD, BRAY GA, HONG Y, STERN JS, PI-SUNYER FX, ECKEL RH: Obesity and cardiovascular disease. Pathophysiology, evaluation, and effect of weight loss. Arterioscler Thromb Vasc Biol 26: 968-976, 2006.

RAINWATER DL, COMUZZIE AG, VANDEBERG JL, MAHANEY MC, BLANGERO J: Serum leptin levels are independently correlated with two measures of HDL. Atherosclerosis 132: 237-243, 1997.

RITCHIE RH: Evidence for a casual role of oxidative stress in the myocardial complications of insulin resistance. Heart Lung Circ 18: 11-18, 2009.

ROSITO GA, MASSARO JM, HOFFMANN U, RUBERG FL, MAHABADI AA, VASAN RS, O'DONNELL CJ, FOX CS: Pericardial fat, visceral abdominal fat, cardiovascular disease risk factors, and vascular calcification in a community-based sample: The Framingham Heart Study. Circulation 117: 605-613, 2008.

ROSS R, GLOMSET J: Studies of primate arterial smooth muscle cells in relation to atherosclerosis. Adv Exp Med Biol 43: 265-279, 1973.

ROUBICEK T, DOLINKOVA M, BLAHA J, HALUZIKOVA D, BOSANSKA L, MRAZ M, KREMEN J, HALUZIK M: Increased angiotensinogen production in epicardial adipose tissue during cardiac surgery: possible role in a postoperative insulin resistance. Physiol Res 57: 911-917, 2008.

SACKS HS, FAIN JN: Human epicardial adipose tissue: A review. Am Heart J 153: 907-917, 2007.

SALGADO-SAMOZA A, FERNANDEZ ET, FERNANDEZ AL, GONZALEZ-JUANATEY JR, EIRAS S: Proteomic analysis of epicardial and subcutaneous adipose tissue reveals differences in proteins involved in oxidative stress. Am J Physiol Heart Circ Physiol 299: 202-209, 2010.

SARIN S, WENGER C, MARWAHA A, QURESHI A, GO BD, WOOMERT CA, CLARK K, NASSEF LA, SHIRANI J: Clinical significance of epicardial fat measured using cardiac multislice computed tomography. Am J Cardiol 102: 767-771, 2008.

SCHWENK RW, LUIKEN JJ, BONEN A, GLATZ JF: Regulation of sarcolemmal glucose and fatty acid transporters in cardiac disease. Cardiovasc Res 79: 249-258, 2008.

SCOTT EM, GRANT PJ: Neel revisited: the adipocyte, seasonality and type 2 diabetes. Diabetologia 49: 1462-1466, 2006.

SHARMA S, ADROGUE JV, GOLFMAN L, URAY I, LEMM J, YOUKER K, NOON GP, FRAZIER OH, TAEGTMEYER H: Intramyocardial lipid accumulation in the failing human heart resembles the lipotoxic rat heart. FASEB J 18: 1692-1700, 2004.

SHAW JE, CHISHOLM DJ: Epidemiology and prevention of type 2 diabetes and the metabolic syndrome. Med $J$ Aust 179: 379-383, 2003.

SILAGHI A, PIERCECCHI-MARTI MD, GRINO M, LEONETTI G, ALESSI MC, CLEMENT K, DADOUN F, DUTOUR A: Epicardial adipose tissue extent: relationship with age, body fat distribution, and coronaropathy. Obesity 16: 2424-2430, 2008. 
SIRONI AM, GASTALDELLI A, MARI A, CIOCIARO D, POSITANO V, BUZZIGOLI E, GHIONE S, TURCHI S, LOMBARDI M, FERRANNINI E: Visceral fat in hypertension: influence of insulin resistance and b-cell function. Hypertension 44: 127-133, 2004.

STEINBUSCH LK, SCHWENK RW, OUWENS DM, DIAMANT M, GLATZ JF, LUIKEN JJ: Subcellular trafficking of the substrate transporters GLUT4 and CD36 in cardiomyocytes. Cell Mol Life Sci 68: 2525-2538, 2011.

SYLVEN C: Mechanisms of pain in angina pectoris - a critical review of the adenosine hypothesis. Cardiovasc Drugs Ther 7: 745-759, 1993.

TACKE F, ALVAREZ D, KAPLAN TJ, JAKUBZICK C, SPANBROEK R, LLODRA J, GARIN A, LIU J, MACK M, VAN ROOIJEN N, LIRA SA, HABENICHT AJ, RANDOLPH GJ: Monocyte subsets employ CCR2, CCR5, and CXCR1 to accumulate within atherosclerotic plaques. J Clin Invest 117: 185-194, 2007.

TRACHTA P, DRAPALOVA J, KAVALKOVA P, TOUSKOVA V, CINKAJZLOVA A, LACINOVA Z, MATOULEK M, ZELINKA T, WIDIMSKY J JR, MRAZ M, HALUZIK M: Three months of regular aerobic exercise in patients with obesity improve systemic subclinical inflammation without major influence on blood pressure and endocrine production of subcutaneous fat. Physiol Res 63 (Suppl 2): S299-S308, 2014.

URBANOVA M, DOSTALOVA I, TRACHTA P, DRAPALOVA J, KAVALKOVA P, HALUZIKOVA D, MATOULEK M, LACINOVA Z, MRAZ M, KASALICKY M, HALUZIK M: Serum concentrations and subcutaneous adipose tissue mRNA expression of omentin in morbid obesity and type 2 diabetes mellitus: the effect of very-low-calorie diet, physical activity and laparoscopic sleeve gastrectomy. Physiol Res 63: 207-218, 2014.

VAN DER MEER RW, RIJZEWIJK LJ, DE JONG HW, LAMB HJ, LUBBERINK M, ROMIJN JA, BAX JJ, DE ROOS A, KAMP O, PAULUS WJ, HEINE RJ, LAMMERTSMA AA, SMIT JW, DIAMANT M: Pioglitazone improves cardiac function and alters myocardial substrate metabolism without affecting cardiac triglyceride accumulation and high-energy phosphate metabolism in patients with well-controlled type 2 diabetes mellitus. Circulation 119: 2069-2077, 2009.

WALECKI J, MICHALAK MJ, MICHALAK E, BILINSKA ZT, RUZYLLO W: Usefulness of 1H MR spectroscopy in the evaluation of myocardial metabolism in patients with dilated idiopathic cardiomyopathy: pilot study. Acad Radiol 10: 1187-1192, 2003.

WARD MR, JEREMIAS A, HIBI K, HERITY NA, LO ST, FILARDO SD, LEE DP, FITZGERALD PJ, YEUNG AC: The influence of plaque orientation (pericardial or myocardial on coronary artery remodeling. Atherosclerosis 154: 179-183, 2001.

WHEELER GL, SHI R, BECK SR, LANGEFELD CD, LENCHIK L, WAGENKNECHT LE, FREEDMAN BI, RICH SS, BOWDEN DW, CHEN MY, CARR JJ: Pericardial and visceral adipose tissue measured volumetrically with computed tomography are highly associated in type 2 diabetic families. Invest Radiol 40: 97-101, 2005. 